\title{
Affective commitment through further training: the roles of firm provision and employee participation
}

\section{Christian Grund $^{1} \cdot$ Krystina Titz $^{1}$}

Received: 18 July 2019 / Accepted: 5 March 2021 / Published online: 22 June 2021

(c) The Author(s) 2021

\begin{abstract}
This study investigates the relation of further training and employees' affective commitment by disentangling the relevance of a firm's general support for further training and the individual's actual participation. Using linked employer-employee data, we consider both the firm's and the individual's perspective and control for several HR instruments additionally to the usual demographics and job characteristics. We also distinguish between subgroups of employees regarding age and schooling. Results show that employees' participation in further training and a firm's support for further training are both positively related to affective commitment. Furthermore, our results hint for differences in employees' expectations regarding the amount of the firm's support for further training. Whereas there is no meaningful relation of the general firm's support for further training to commitment of university graduates, participation in further training measures and the individuals' perceived support for personnel development is particularly relevant for this group of employees.
\end{abstract}

Keywords Commitment · Further training · Signalling · Linked employer-employee data

Mathematics Subject Classification 62H15

\section{Introduction}

"Employees are a company's greatest asset" (Anne M. Mulcahy, former CEO and chairwoman of Xerox Corporation). This statement has been used in a similar way by leaders of many companies and may sound like a well-worn phrase by now. It

Christian Grund

christian.grund@hrm.rwth-aachen.de

Krystina Titz

krystina.titz@hrm.rwth-aachen.de

1 School of Business and Economics, Chair of Human Resource Management and Personnel Economics, RWTH Aachen University, Templergraben 64, 52056 Aachen, Germany 
expresses the particular meaning of a productive workforce and their retention, though. It is therefore not surprising that employees' commitment towards their organizations has become a widely discussed topic over the last twenty-five years. Empirical work indicates strong associations between commitment and important outcome variables for organizations, such as lower absenteeism and turnover rates as well as higher performance and productivity levels of employees (Randall 1990; Cooper-Hakim and Viswesvaran 2005). This is true for the affective component of organizational commitment in particular (Mowday et al. 1979; Allen and Meyer 1990; Meyer et al. 2002; Bergman 2006) so that Mercurio (2015) concludes in his survey that affective commitment is the "enduring, demonstrably indispensable, and central characteristics of organizational commitment". Hence, a key question for human resource management in organizations is that of how to ensure the affective commitment of employees. The meta-analyses by Mathieu and Zajac (1990) and Meyer et al. (2002) show different measures for organizations which are significantly positively related to employees' (affective) commitment, such as the employees' perception of fairness regarding the communication with, decision procedures of, performance appraisal by and feedback from the leader and the perceived task autonomy.

Most firms conduct further training measures in order to maintain or to increase employees' productivity by improving employees' knowledge and skills. In many cases, this also comes along with better employment possibilities at other firms. Therefore, it is important to shed light onto the relationship between further training and affective commitment.

Previous studies look at single facets of further training: Some contributions rely on employees' perceptions of a firm's support toward training measures and mostly find a positive link to their affective commitment (Meyer and Smith 2000; Bartlett 2001; Ahmad and Bakar 2003; Lee and Bruvold 2003; Bartlett and Kang 2004; AlEmadi and Marquardt 2007; Bulut and Culha 2010; Ling et al. 2014; Bashir and Long 2015; Kooij and Boon 2018). These studies cannot fully rule out a possible common method bias, though. Other studies explore the link between participation in training and commitment (Roehl and Swerdlow 1999; Benson 2006; Cao and Hamori 2015). These contributions focus on specific occupation groups based on rather a small number of observations and do not comprise a more representative sample of employees. Two studies based on representative samples do not investigate commitment but related issues such as employee turnover (Kampkötter and Marggraf 2015) or retention (Dietz and Zwick 2020).

Training possibilities for employees can be very different across firms. It may be the case that a firm's general provision of training measures is also related to employee commitment without a necessary own participation in training. Some contributions take the firm's perspective into account and study the link between the general provision of training by the firm and employees' commitment (Wentland 2003; Chew and Chan 2008).

We add to the literature by combining the individual and firm perspective and use representative data. We investigate the role of employees' participation in training as well as the firms' provision of training for affective commitment. We make use of the German Linked Personnel Panel (LPP), which combines firm-based information with information provided by several of those employees. For sure, firms may also 
differ in other commitment-relevant aspects not measured in the data. We therefore use the level of commitment of other employees of a firm as an additional control to capture some of these differences. This type of firm differences has not been considered in previous work. Moreover, we explore the relation between further training and affective commitment for different groups of employees. When we refer to further training in this contribution, we rather think of formal courses for firm employees than of apprenticeship training, onboarding activities for new hires, or informal on-the-job-training.

The remainder of this contribution is structured as follows: In Sect. 2 we derive hypotheses from theoretical considerations and related previous empirical work. Then we describe the data and the empirical strategy in Sect. 3 followed by the presentation of our results in Sect. 4. In Sect. 5, we discuss the results, mention some limitations, and conclude.

\section{Theoretical background and previous empirical work}

Meyer and Allen (1991) established the three-component concept of organizational commitment, which consists of the three constructs "affective commitment", "continuance commitment" and "normative commitment". The first of these describes the emotional component of employees and their psychological attachment towards the organization. The construct is defined as follows: "Employees with strong affective commitment remain because they want to, those with strong continuance commitment because they need to, and those with strong normative commitment because they feel they ought to do so" (Allen and Meyer 1990, p. 3). Affectively committed individuals identify with their organization, since the values and goals of the organization go along with employees' perceptions. For this reason, the individual develops a feeling of pride and loyalty towards the organization (Mowday et al. 1979). Previous literature considers the affective component as an important core essence of organizational commitment which is more strongly correlated to important outcome variables of organizations such as turnover, absence, and performance than the normative and continuance component (Mercurio 2015). For this reason, our research focuses on the affective component of organizational commitment. Meyer et al. (1993) developed and validated a scale to explicitly measure the affective commitment of employees based on the Organizational Commitment Questionnaire (OCQ) of Porter et al. (1974).

As argued above, it is then a relevant question as to what extent affective commitment is related to participation in training measures by taking the firms' provision of training into account. We explore both facets in this contribution.

A possible relation between training and commitment is not obvious for all training measures and will not necessarily occur if training is mandatory or statutory (Newman et al. 2011). ${ }^{1}$ Besides, training measures can be seen as an investment in

\footnotetext{
${ }^{1}$ Evidence based on a sample of nurses in public hospitals suggests, however, that even the perceived access to mandatory training can be positively related to organizational commitment (Bartlett 2001).
} 
human capital from an economic point of view (Becker 1962). Then, a firm's decision to offer training for certain employees will be based on cost-benefit-considerations with regard to employees' expected post-training productivity. However, participation in training may increase the recipients' value both within the firm and in the external labour market, so that the relation to organizational commitment is not that clear from this perspective.

Decisions about offering training may also be interpreted as part of the social exchange between firms and employees, though. According to social exchange and gift exchange concepts, individuals will reciprocate gestures of goodwill in the future in response to a beneficial act (Blau 1964; Akerlof 1982). The question arises of whether training measures can be perceived as a gift. For sure, not every offered training measure needs to be a gift from the firm or is perceived as such by employees. This may apply for mandatory training measures or if the employer uses training measures as a non-monetary benefit in order to reward employees' past performance. However, other training may be perceived as a gift. Indeed, Settoon et al. (1996) use this consideration and the norm of reciprocity is a characteristic of both the social exchange concept and the gift exchange approach (Gouldner 1960; Fehr and Gächter 2000). Experimental work which uses trust or gift-exchange games shows that participants do react in a reciprocal way. Hence, taking general training measures into account, employees can perceive participation in employer-provided further training as a gift from their firm, since the provided skills increase employees' employment possibilities at other firms. Then - as a gift given in return - the employees increase their positive attitudes, such as affective commitment, towards their organization (Akerlof 1982, 1984).

Another relevant approach for analyzing the relation of further training and individual affective commitment is the social identity theory which focuses on the behavior of individuals in groups (Tajfel 1974; Hogg et al. 1995). The development of employees in organizations focuses on the alignment with the goals of organizations such that further training of employees might still increase the social identity of an employee towards his or her organization. The positive relationship between social identity and affective commitment is well established (e.g. Ashford and Mael 1989; Pratt 1998; Bergami and Bagozzi 2000; Meyer and Herscovitch 2001; Foreman and Whetten 2002; Van Vugt and Hart 2004; Meyer et al. 2006), which again leads to our expected positive relation between training and commitment even if training is not considered as a gift.

Empirical results based on field data for the explicit relation between training participation and affective commitment are scarce. Some studies focus on the relation between training and turnover (intentions) as a possible consequence of a lack of commitment (Sieben 2007; Kampkötter and Marggraf 2015) or a positive relation between training and retention of employees (Dietz and Zwick 2020). Based on a cross-sectional analysis of one particular firm, Benson (2006) finds first evidence for a positive relation between participation in training measures and affective commitment in a high-technology manufacturing firm. Cao and Hamori (2015) find no significant relation between participation in training and commitment in a small sample of professionals.

Based on these concepts and findings, we expect that employees can perceive participation in further training as a gift from their firm. Employees feel as though 
they are valued by and important to their firm, so they react in a reciprocal way and consequently develop a higher affective commitment to the firm. This leads to the following.

Hypothesis 1 Participation in further training is positively related to affective commitment of employees.

Next to the actual participation in formal training measures, a general support of the firm for further training may have its own relevance for commitment. According to signaling theory, people interpret organizations' observable actions as signals of less observable firm characteristics (Spence 1973; Butts et al. 2013). In this sense, the general availability of further training in a firm can be interpreted as a signal that the organization cares about its employees in general and treats them adequately and abstains from opportunistic behavior. Many facets of potential employer opportunism may not be observed easily by employees. For example, employees do not know whether the firm will reply to a potential crisis by (unnecessary) mass dismissals or by keeping the workforce. Since training is costly in the first instance, its general support by the firm may act as a credible signal to be an attractive employer. As an empirical example, Backes-Gellner and Tuor (2010) find that firms offering apprenticeship training programs improve the recruitment success for skilled employees and ascribe this relation by a reliable signal for an appealing workplace. Besides, Gilani and Cunningham (2017) review the literature on employer branding and find, in accordance with the above considerations, that training is one of seven key themes regarding the relation between employer branding and employee retention.

Additionally, perceived organizational support theory indicates that employees develop a belief of the extent to which the organization cares about their well-being, which leads to obligations within individuals to return something positive (Eisenberger et al. 1986; Settoon et al. 1996). The employees might reciprocate through higher affective commitment. Compared to participation in training, which refers to the present situation of the employee, support can be more related to future employment relationship and corresponding individuals' expectations. This leads to our second hypothesis:

Hypothesis 2 A firm's general support for further training is positively related to the individual affective commitment of employees.

Combining the considerations pointed out above leads to the key question of our paper: Is a firm's support for further training sufficient to ensure high levels of affective commitment of employees or is actual participation in further training a prerequisite? The above-mentioned previous empirical studies either concentrate on the relation of firm's support for training or examine individual participation in training and affective commitment. They do not investigate a possible link between the two facets. We address this open empirical question within this contribution. Hence, we explore whether possible relations expressed in hypotheses 1 and 2 also hold when considering both facets simultaneously. 
Based on hypothesis 2 we analyze the relation between the firm's support for training and affective commitment in more detail, since we assume that the relationship between a firm's support for training and commitment may differ among various groups of individuals. The firm's support for training may be much more important for younger employees because of possible career prospects. Kooij et al. (2010) distinguish maintenance from development HR practices and point out in their metastudy that the association between training and work-related attitudes weakens with age. Grund (2013) measures job preferences with advancements in job characteristics in coincidence with employee-initiated job changes. Again, the results hint at a particular relevance of preferences towards personnel development for younger and better educated employees. These groups report particular advancements in terms of possibilities of personal development subsequent to job changes initiated by themselves. This evidence suggest that training opportunities are more important for younger and better educated employees. If this is the case, commitment towards their organization will suffer for these groups in particular, if expectations are not met. In contrast, less educated and older employees may in fact be positively surprised by training opportunities. However, the evidence reported above suggests that training is less important for these groups of employees. This may result in relevant interaction effects between firms' support for training and both age and education. Hence, our considerations directly lead to.

Hypothesis 3 a: The relation between firms' support for training and affective commitment is relevant for younger employees in particular.

Hypothesis 3 b: The relation between firms' support for training and affective commitment is relevant for better-educated employees in particular.

One may also think about differences between female and male employees. However, Konrad et al. (2000) show in a meta-study that sex differences in job attribute preferences were already diminished in the 80 s and 90 s of the twentieth century compared to the 70s. We therefore do not consider specific gender effects.

\section{Method}

\subsection{Data and sample}

The analysis is based on the Linked Personnel Panel (LPP), which is a linked employer-employee data set of establishments and several of their employees in Germany (Bellmann et al. 2015). On the establishment level, the LPP is representative of German establishments with 50 and more employees in the manufacturing and in the service sector. We make use of the first two waves of the LPP (2013 and 2015). The unit of observation is the individual in a year. The data contain rich information on the individual level from several employees per firm. This information is linked to firm information given by the managing director or HR manager of each firm. 
Moreover, the LPP can be linked to the IAB establishment panel, which includes additional establishment information. ${ }^{2}$ We restrict our sample to employees who reported valid information about their affective commitment and are between 21 and 65 years old. Our unbalanced panel includes 8,469 observations of 7,000 individuals in 837 firms.

\subsection{Measures}

\subsubsection{Affective commitment}

Our dependent variable affective commitment is computed as a standardized (z-scored) index measured by six items with possible answers from 1 (does not apply at all) to 5 (fully applies) based on the affective commitment questionnaire of Allen and Meyer (1990). They developed a short form and scale of affective commitment which is part of the LPP. For example, the participants are asked to respond to "I would be very happy to spend the rest of my career with this organization", "This organization has a great deal of personal meaning for me", "I really feel as if this organization's problems are my own" and three items are asked on a reversed scale. $^{3}$

\subsubsection{Further training}

To find out whether the support or the participation effect prevails for the relationship between further training and affective commitment, the following variables are considered as well: We measure the support effect from the firm's perspective by using two variables. First, there is information, on the firm level, on the availability of further training in the firm, such as firm's support for further training, which is a binary variable. The employers declare whether they had actively supported employees' qualification activities in the last two years, e.g. by releasing them from work or at least partially bearing the costs. Second, the firm's training volume is measured as the total number of participants in further training divided by the total number of employees. ${ }^{4}$ This variable is also measured on firm level and depicts an alternative for examining the support effect. In order to measure the participation effect, we use the variable participation in further training on the individual level, which adopts 1 if the employee has taken part in any courses of further training in the most recent year and 0 otherwise.

\footnotetext{
${ }^{2}$ Data access was provided via on-site use at the Research Data Centre (FDZ) of the German Federal Employment Agency (BA) at the Institute for Employment Research (IAB) and subsequently remote data access. The project-number is fdz1234.

3 These items are taken from the affective commitment short form and scale of Meyer et al. (1993). For a detailed list of the items, see Table A in the appendix and Kampkötter et al. (2016).

4 The information about "Total number of participants in further training" refers to a period of time in the survey (the first half of a particular year), whereas the information about "Total number of employees" refers to a point in time (30 June of a particular year).
} 
Table 1 Means, standard deviations, and correlations among main variables

\begin{tabular}{llclll}
\hline & Mean/Share & SD & 1 & 2 & 3 \\
\hline 1. Affective commitment & 3.70 & 0.89 & & & \\
2. Participation in further training $(1=$ yes $)$ & 0.36 & - & $0.13^{* * *}$ & & \\
3. Firm's support for further training $(1=y e s)$ & 0.79 & - & $0.10^{* * *}$ & $0.08^{* * *}$ & \\
4. Firm's training volume & 0.37 & 0.34 & $0.07 * * *$ & $0.13^{* * *}$ & $0.19^{* * *}$ \\
\hline
\end{tabular}

Notes: $\mathrm{n}=8,469$. Not standardized information of affective commitment; from now on the affective commitment is used as a $\mathrm{z}$-standardized variable. $* * *$ significant at $1 \%$

On average, employees report a level of affective commitment of about 3.7 (on the scale from 1 to 5). More than third of the employees participated in further training during the years 2012 and 2014 (Table 1). Consistently, this fraction is also given from the firm side when reporting their training volume. ${ }^{5}$ Four out of five firms declare that they support their employees in further training.

\subsubsection{Controls}

The results of a case study by Jorgensen and Becker (2015) on three Danish investment firms and focussing on new hires within the onboarding process suggest that several HR practices can play a role for organizational commitment. Moreover, the amount of pay and the feasible benefits are positively related to the affective commitment of employees (Meyer and Smith 2000). Thus, we also use information from the employer survey in order to control for numerous human resource management instruments. These may either signal to employees that their firm cares about them or are perceived as monitoring devices. We consider the availability of development and staffing plans, the conduction of appraisal interviews and employee surveys, the existence of target agreements, and participation in auditing processes, for instance. We use these variables as control variables for the support effect regarding a firm's support for further training. Neglecting these HR instruments may otherwise lead to an omitted variable bias, because these instruments are significantly correlated to the provision of further training. ${ }^{6}$

Further control variables for employees' participation in certain human resource management instruments are the appraisal interview of employees with their superior in the most recent year and whether working from home is feasible. Furthermore, we control for the average affective commitment of other firm employees by computing the mean of the affective commitment of all employees, excluding the particular individual, in order to control for a potential spill-over commitment effect and capturing some unobserved firm effects.

\footnotetext{
5 Other studies using German panel find similar rates for training volume (e.g. Stegmeier 2012). Earlier studies report somewhat lower training rates, which increase over time, though (Becker 1991). Since only firms with at least 50 employees are part of the LPP and training is more relevant in larger firms, it is not surprising that training participation/training volume is rather high in our sample.

6 See Table B in the appendix for detailed correlations.
} 
We also control for socio-demographic variables as well as for individual jobrelated and further firm characteristics, such as employment situation and leadership position, part-/full-time, wage, collective agreement, work's council, firm size, region and industry. Most of these variables have been identified as relevant for (affective) commitment in previous studies (Meyer and Smith 2000; Meyer et al. 2002; Ahmad and Bakar 2003, Erdheim et al. 2006, Jirjahn 2018 and Bellmann et al. 2018).

About 0.73 employees of our sample are male (Table 2). On average, the employees are 46 years old, 0.84 are in a relationship, and 0.25 of them have children under 14 years. On average, the employees exhibit 12.54 years of education. About 0.88 of them work full-time and at least earn $€ 3,459$ per month. Two out of five individuals have either a blue collar or a white collar position, whereas 0.2 work as a manager with some kind of leadership tasks. About half of the employees participated in appraisal interviews with their supervisors. Only 0.14 of the employees are allowed to work from home.

About 0.71 of the sample consists of firms with collective wage agreements and 0.35 are firms with 500 and more employees. In addition, about 0.68 of the firms are in the processing, metal, and electrical industries. About 0.79 of the firms have staffing plans and target agreements for their employees, conduct appraisal interviews, and participate in certification and auditing processes. Almost two thirds of firms have development plans for their employees and half of them conduct employee surveys.

A share of 0.29 of employees who have participated in further training $(n=3,066)$ are managers. Only 0.16 of employees who have not participated in further training $(n=5,403)$ are managers. Employees who have participated in further training tend to work from home $(0.25)$, are more likely to participate in appraisal interviews (0.63), and earn on average $700 €$ more than employees who have not participated in further training. Moreover, employees who have participated in further training tend to work in firms which implement HR instruments more frequently than employees do who have not participated in further training.

\subsection{Empirical Strategy}

We apply OLS estimations in order to analyze the relation of further training and affective commitment. ${ }^{7}$ The following equation describes our empirical approach to investigate the link between training and commitment:

$A C_{i, t}=\beta_{0}+\beta_{1} *$ training variable $(s)_{i, t}+\gamma *$ controls $_{i, t}+\varepsilon_{i, t}$.

$A C_{i, t}$ represents the individual affective commitment of employees. We first insert the binary variable participation in further training $(1=y e s)$ as training variable on the individual level, which is our main measure for the participation effect as described above. Second, we include the dummy variable firm's support for further training $(1=$ yes) and firm's training volume as training variables on the firm level

\footnotetext{
7 The within person variation with regard to both affective commitment and the training variables is not sufficient to apply sensible fixed-effects estimations.
} 


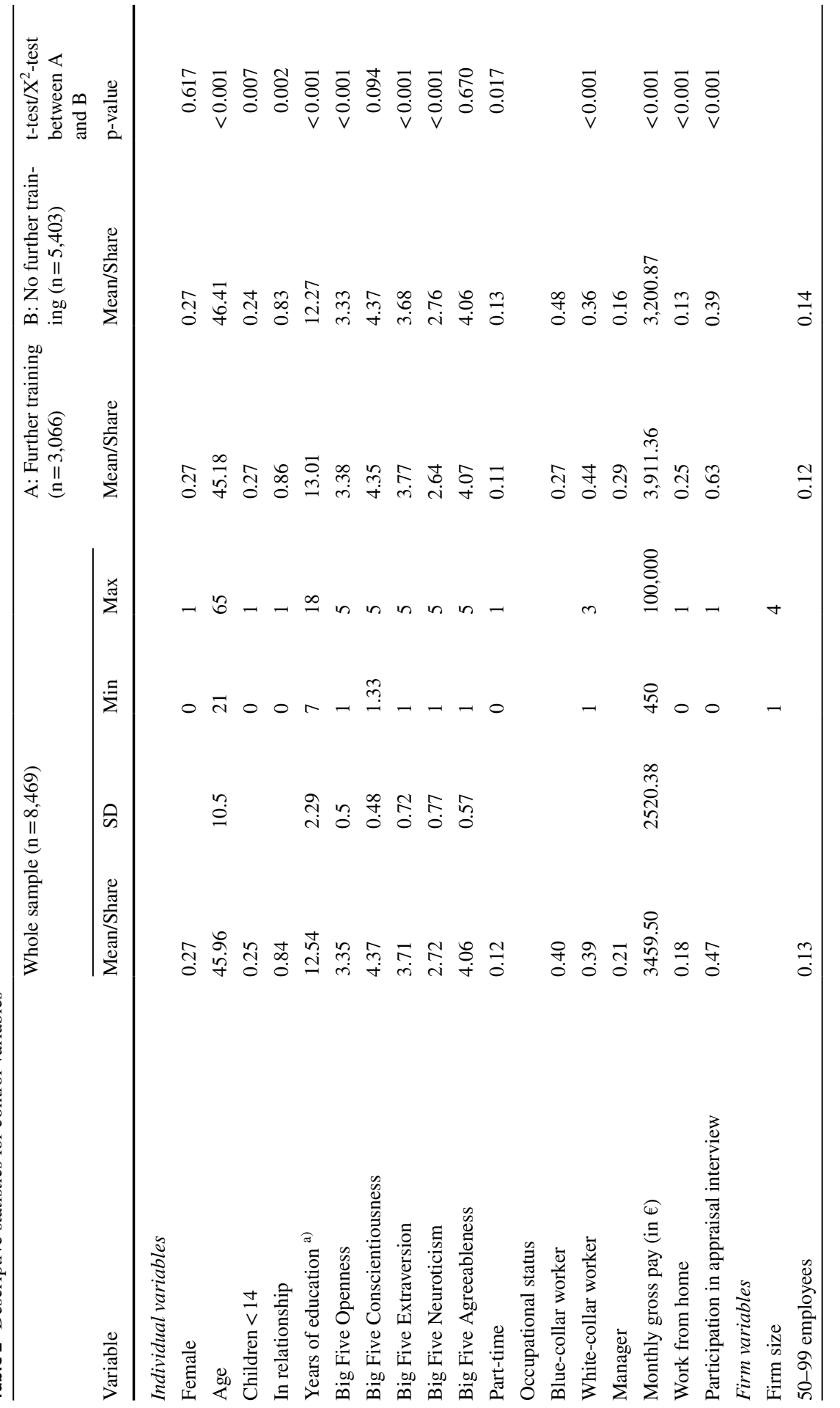




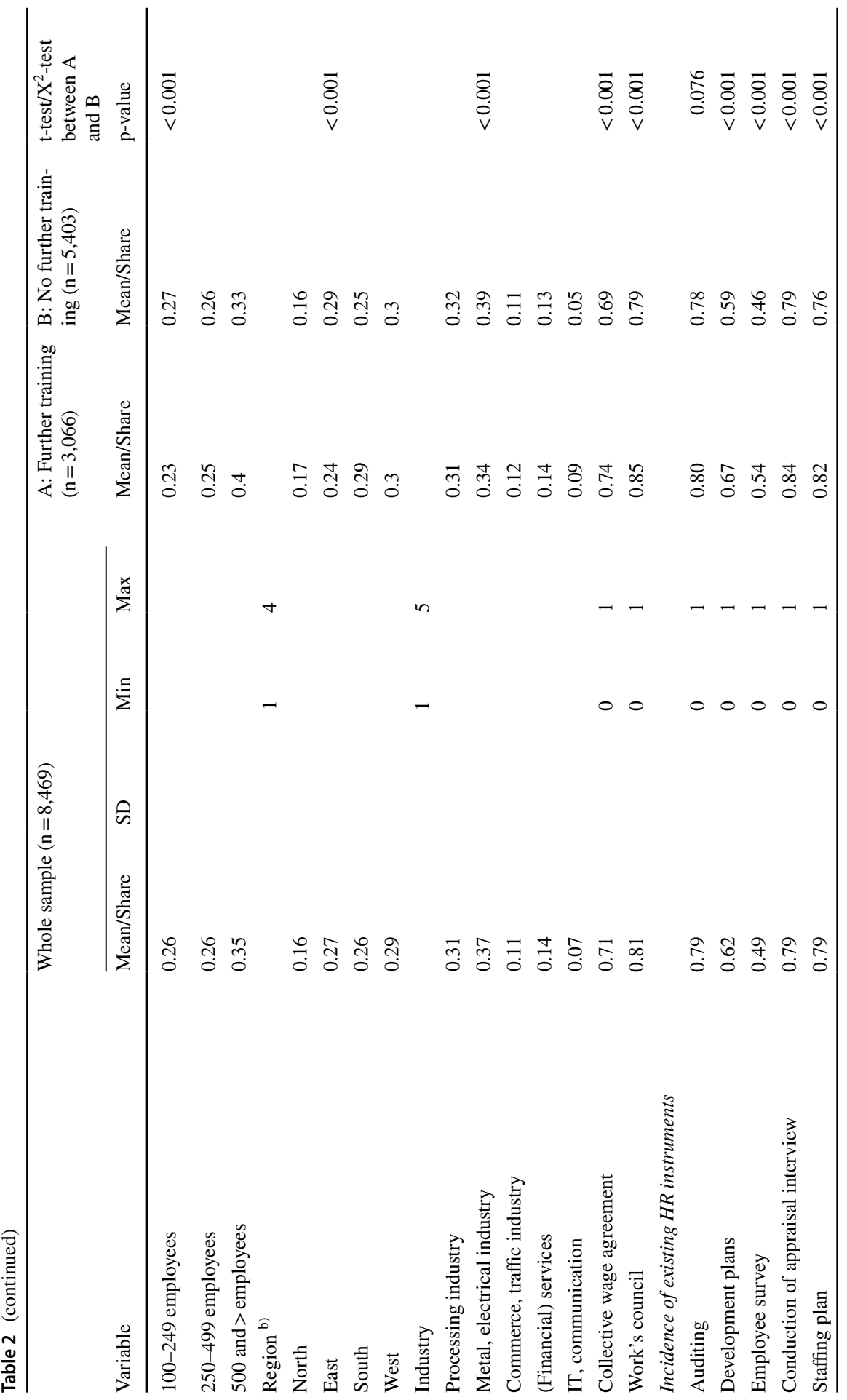




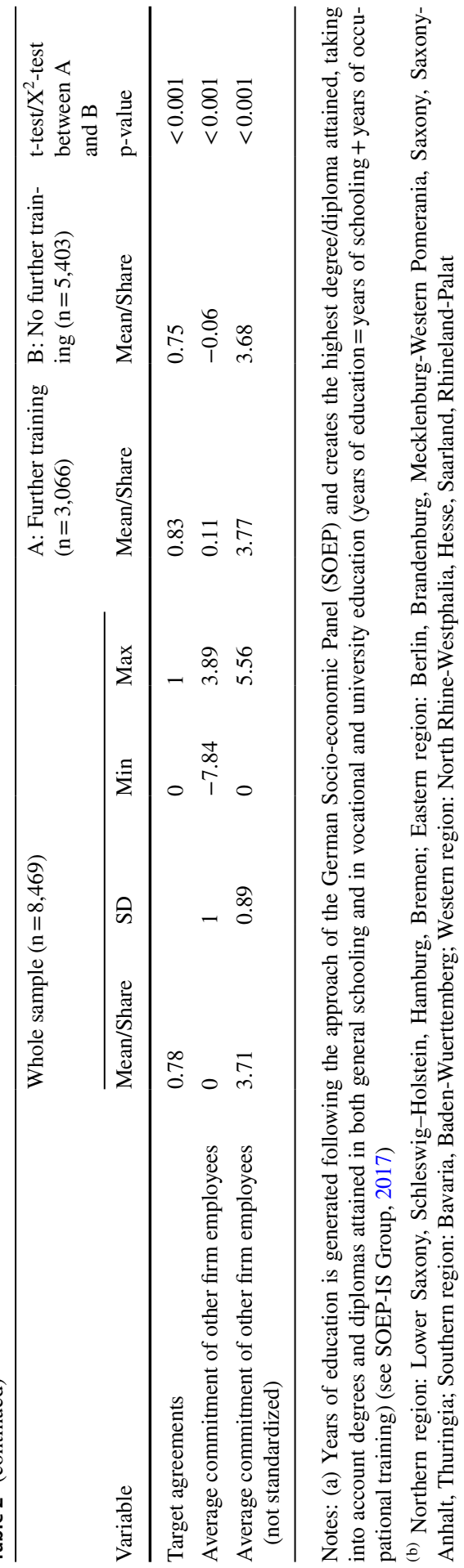


separately in order to analyze the support effect. Third, we provide a joint estimation with all training measures. Controls is a vector of socio-demographic, individual job-related variables and firm characteristics as well as control variables for employees' participation in or a firm's support for HR instruments as mentioned above. Furthermore, we control for the average affective commitment of other firm employees. By clustering robust standard errors at the firm level, we take some firm differences into account.

Finally, we interact the firms' support for training with years of education of individuals and age in order to test hypotheses (3a) and (3b).

\section{Results}

We start our empirical analysis by examining the relation of participation in further training and affective commitment. The results of the OLS estimations with affective commitment as our dependent variable are reported in Table 3. Model (1) includes information on socio-demographics and individual job-related variables as well as firm characteristics which have been identified as relevant variables for affective commitment in previous studies (Mathieu and Zajac 1990; Meyer and Smith 2000; Meyer et al. 2002; Ahmad and Bakar 2003). Employees' participation in further training is significantly and positively related to the individual affective commitment.

Results with regard to our controls include that women and older employees are significantly more highly affectively committed than men and younger employees. We also find a highly significant and positive relation of gross pay and affective commitment. Besides, managers exhibit a significantly higher affective commitment than blue-collar workers do. Additionally, the part-time dummy is significant positive. We have to note, however, that we control for monthly wages. Indeed, average commitment of full-time employees in our sample is somewhat higher than it is among part-time workers (3.71 vs. 3.64) and the sign of the part-time employees turns around when not controlling for monthly wages. Moreover, there is a significant negative relation of employees' years of education and their affective commitment (controlled for job and firm characteristics). The higher an employee's education, the more valuable that employee is to other firms on the market, which can reduce her or his affective commitment to the current firm. Moreover, employees who work in firms with collective wage agreements and/or with work's councils show a higher affective commitment in comparison.

In order to disentangle the possible impact of further training on affective commitment from that of other management instruments, we additionally control for the incidence of several further HR instruments in Model (2). Employees who participated in appraisal interviews with their supervisors are significantly more highly affectively committed than employees who have not taken part in such interviews. Furthermore, employees who cannot work from home have a significantly lower affective commitment than employees who are able to work from home. Moreover, employees working in firms which have employee surveys and staffing plans are significantly more highly affectively committed compared to employees who work in 
Table 3 Participation in further training and affective commitment (OLS)

\begin{tabular}{|c|c|c|c|}
\hline & \multicolumn{3}{|c|}{ Affective commitment } \\
\hline & (1) & (2) & (3) \\
\hline Participation in further training & $\begin{array}{r}0.1964 * * * \\
(0.0228)\end{array}$ & $\begin{array}{r}0.1659 * * * \\
(0.0229)\end{array}$ & $\begin{array}{l}0.1586 * * * \\
(0.0225)\end{array}$ \\
\hline Female & $\begin{array}{r}0.0853 * * * \\
(0.0302)\end{array}$ & $\begin{array}{l}0.0790 * * * \\
(0.0298)\end{array}$ & $\begin{array}{l}0.0739 * * \\
(0.0292)\end{array}$ \\
\hline Age & $\begin{array}{r}0.0169 * * * \\
(0.0011)\end{array}$ & $\begin{array}{r}0.0176^{* * * *} \\
(0.0011)\end{array}$ & $\begin{array}{l}0.0177 * * * \\
(0.0011)\end{array}$ \\
\hline Children $<14$ & $\begin{array}{l}0.0274 \\
(0.0252)\end{array}$ & $\begin{array}{l}0.0258 \\
(0.0250)\end{array}$ & $\begin{array}{l}0.0326 \\
(0.0249)\end{array}$ \\
\hline In relationship & $\begin{array}{l}0.0298 \\
(0.0293)\end{array}$ & $\begin{array}{l}0.0193 \\
(0.0294)\end{array}$ & $\begin{array}{l}0.0151 \\
(0.0295)\end{array}$ \\
\hline Years of education & $\begin{array}{c}-0.0387 * * * \\
(0.0053)\end{array}$ & $\begin{array}{c}-0.0434 * * * \\
(0.0055)\end{array}$ & $\begin{array}{l}-0.0424 * * * \\
(0.0054)\end{array}$ \\
\hline Big five openness & $\begin{array}{l}0.0518 * * \\
(0.0248)\end{array}$ & $\begin{array}{l}0.0419 * \\
(0.0246)\end{array}$ & $\begin{array}{l}0.0411 * \\
(0.0245)\end{array}$ \\
\hline Big five conscientiousness & $\begin{array}{r}0.0722 * * * \\
(0.0247)\end{array}$ & $\begin{array}{r}0.0743 * * * \\
(0.0246)\end{array}$ & $\begin{array}{l}0.0795 * * * \\
(0.0247)\end{array}$ \\
\hline Big five extraversion & $\begin{array}{r}0.0968 * * * \\
(0.0162)\end{array}$ & $\begin{array}{l}0.0913 * * * \\
(0.0160)\end{array}$ & $\begin{array}{l}0.0881 * * * \\
(0.0161)\end{array}$ \\
\hline Big five neuroticism & $\begin{array}{l}-0.0156 \\
(0.0156)\end{array}$ & $\begin{array}{l}-0.0124 \\
(0.0155)\end{array}$ & $\begin{array}{l}-0.0121 \\
(0.0155)\end{array}$ \\
\hline Big five agreeableness & $\begin{array}{r}0.1398 * * * \\
(0.0204)\end{array}$ & $\begin{array}{r}0.1397 * * * \\
(0.0204)\end{array}$ & $\begin{array}{l}0.1377 * * * \\
(0.0203)\end{array}$ \\
\hline Part-time & $\begin{array}{r}0.2203 * * * \\
(0.0393)\end{array}$ & $\begin{array}{r}0.1947 * * * \\
(0.0386)\end{array}$ & $\begin{array}{l}0.1782 * * * \\
(0.0380)\end{array}$ \\
\hline \multicolumn{4}{|l|}{$\begin{array}{l}\text { Employment situation } \\
\text { (Reference:Blue-collar worker) }\end{array}$} \\
\hline White-collar worker & $\begin{array}{l}0.0395 \\
(0.0276)\end{array}$ & $\begin{array}{l}0.0147 \\
(0.0273)\end{array}$ & $\begin{array}{l}0.0111 \\
(0.0271)\end{array}$ \\
\hline Manager & $\begin{array}{l}0.1724 * * * \\
(0.032)\end{array}$ & $\begin{array}{r}0.1322 * * * \\
(0.0325)\end{array}$ & $\begin{array}{l}0.1404 * * * \\
(0.0319)\end{array}$ \\
\hline Gross pay (log) & $\begin{array}{l}0.4790 * * * \\
(0.0342)\end{array}$ & $\begin{array}{r}0.4209 * * * \\
(0.0339)\end{array}$ & $\begin{array}{l}0.3945 * * * \\
(0.0331)\end{array}$ \\
\hline Collective agreement & $\begin{array}{l}0.0662 * * \\
(0.031)\end{array}$ & $\begin{array}{l}0.0589^{*} \\
(0.0315)\end{array}$ & $\begin{array}{l}0.0523^{*} \\
(0.0280)\end{array}$ \\
\hline Work's council & $\begin{array}{l}0.0722 * \\
(0.0386)\end{array}$ & $\begin{array}{l}0.0499 \\
(0.0375)\end{array}$ & $\begin{array}{l}0.0300^{*} \\
(0.0332)\end{array}$ \\
\hline \multicolumn{4}{|l|}{ Firm size (Reference: 50-99) } \\
\hline 100-249 employees & $\begin{array}{l}-0.0196 \\
(0.0412)\end{array}$ & $\begin{array}{l}-0.0274 \\
(0.0406)\end{array}$ & $\begin{array}{l}-0.0229 \\
(0.0357)\end{array}$ \\
\hline 250-499 employees & $\begin{array}{l}0.0084 \\
(0.0430)\end{array}$ & $\begin{array}{l}-0.0248 \\
(0.0418)\end{array}$ & $\begin{array}{l}-0.0209 \\
(0.0368)\end{array}$ \\
\hline 500 and $>$ employees & $\begin{array}{l}-0.0260 \\
(0.0446)\end{array}$ & $\begin{array}{l}-0.0664 \\
(0.0445)\end{array}$ & $\begin{array}{l}-0.0555 \\
(0.0392)\end{array}$ \\
\hline
\end{tabular}


Table 3 (continued)

Affective commitment

(1)

Region
(Reference: North)

East

South

West

Industry

(Reference: Processing industry)

Metal, electrical industry

Commerce, traffic industry

(Financial) services

IT, communication

Participation in appraisal interview

Work from home

Auditing

Development plans

Employee survey

Conduction of appraisal interview

Staffing plan

Target agreements

Average commitment of other firm employees

Year-dummy

Adjusted $\mathrm{R}^{2}$

\# Observations
(2)

(3)

$\begin{array}{lll}0.0967 * * & 0.0966 * * & 0.0929 * * * \\ (0.0427) & (0.0403) & (0.0357) \\ 0.0034 & 0.0078 & 0.0019 \\ (0.0429) & (0.0425) & (0.0374) \\ 0.0324 & 0.0396 & 0.0295 \\ (0.0422) & (0.0408) & (0.0357)\end{array}$

$$
\begin{aligned}
& 0.0200 \\
& (0.0291) \\
& -0.0191 \\
& (0.0453) \\
& -0.1506 * * * \\
& (0.0461) \\
& -0.2875 * * * \\
& (0.0642)
\end{aligned}
$$$$
0.0347
$$$$
\text { (0.0291) }
$$$$
0.0324
$$$$
\text { (0.0256) }
$$$$
-0.0222
$$$$
-0.0167
$$$$
\text { (0.0443) }
$$$$
\text { (0.0392) }
$$$$
-0.1592 * * *
$$$$
-0.1289 * * *
$$$$
\text { (0.0437) }
$$$$
\text { (0.0359) }
$$$$
-0.2870 * * *
$$$$
-0.2482 \text { *** }
$$$$
\text { (0.0669) }
$$$$
\text { (0.0585) }
$$$$
0.1854 \text { *** }
$$$$
\text { (0.0231) }
$$$$
0.1770 \text { *** }
$$$$
\text { (0.0224) }
$$

$0.1072 * * *$

0.1061 ***

(0.0326)

(0.0316)

$-0.0334$

$-0.0268$

(0.0265)

(0.0303)

0.0074

(0.0279)

(0.0315)

0.0620 ***

(0.0230)

(0.0262)

$-0.0053$

(0.0313)

(0.0356)

0.0381

0.0457

(0.0343)

(0.0393)

$-0.0568 * *$

(0.0288)

$0.0746 * * *$

(0.0149)

yes

0.1586

yes
0.1434
8,469

yes

0.1539

8,469

Notes: Clustered robust standard errors at firm level in brackets

*significant at $10 \%, * *$ significant at $5 \%, * * *$ significant at $1 \%$ 
Table 4 Support for, participation in further training, and affective commitment (OLS)

Affective commitment

(1)

0.0609
$(0.0373)$

Firm's training volume

Firm's support

for further training

Participation in further training

Controls

Adjusted $\mathrm{R}^{2}$

\# Observations
(2)

(3)

0.0428

(0.0370)

(0.0377)

$0.1379 * * * \quad 0.1334 * * *$

(0.0299)

(0.030)

$0.1271^{* * * *}$

(0.0296)

$0.1529 * * *$

(0.0226)

yes

0.1608

8,469

Notes: Clustered robust standard errors at firm level in brackets

${ }^{*}$ significant at $10 \%$, **significant at $5 \%$, ***significant at $1 \%$. Controls: female $(1=$ yes), age, children $<14$ ( $1=$ yes), in relationship ( $1=$ yes), years of education, big five ( 5 dummies), part-time $(1=$ yes $)$, employment situation $(1=$ yes $)$, gross pay, collective agreement $(1=$ yes $)$, work's council $(1=$ yes $)$, firm size (4 dummies), region (4 dummies), industry (5 dummies), incidence of HR instruments ( 8 dummies), average commitment of other firm employees, year

firms without such surveys and plans. Employees working in firms that agree targets with their employees have a significantly lower affective commitment. The coefficient of participation in further training decreases but is still significantly positively associated with employees' affective commitment.

In Model (3) we add the variable average commitment of other firm employees in order to control for possible firm differences. Including a firm's average commitment of other firm employees indicates a potential spill-over effect, which means that the higher a firm's average commitment of other employees, the higher the individual affective commitment. This shows that differences in the average firm's commitment of employees seem to be relevant for the relation of participation in further training and individual affective commitment. The coefficient of participation in further training is still meaningful and highly statistically significant, which confirms Hypothesis (1). Model (3) points out that employees who participated in further training are more committed to the firm in the amount of 0.16 standard deviations compared to employees who have not participated in further training.

In order to examine the relation of support for further training and the individual affective commitment, we replace participation in training by the two different measures of support in Table 4 and focus on firm's training volume and firm's support for further training on the firm level in Models (1) and (2). We again control for all variables as in Model (3) of Table 3. Firm's training volume does not have an own (Model 1) or additional effect (Model 3) for the affective commitment. However, support for further training is significantly positively related to employees' affective commitment in separate and joint estimations (Models 2 and 3) which is in line with our Hypothesis (2). 
Table 5 Firm's support for further training and affective commitment (interaction terms)

\begin{tabular}{lll}
\hline & $(1)$ & $(2)$ \\
\hline Firm's training volume & $\begin{array}{l}0.0297 \\
(0.0378)\end{array}$ & $\begin{array}{l}0.0289 \\
(0.0378)\end{array}$ \\
Firm's support for further training & 0.0224 & $0.3740 * *$ \\
& $(0.1204)$ & $(0.1502)$ \\
Participation in further training & $0.1529 * * *$ & $0.1529 * * *$ \\
& $(0.0225)$ & $(0.0226)$ \\
Age & $0.0161 * * *$ & $0.0178^{* * *}$ \\
& $(0.0024)$ & $(0.0011)$ \\
Years of education & $-0.0424 * * *$ & $-0.0265^{* *}$ \\
& $(0.0054)$ & $(0.0116)$ \\
Firm's support for further training * age & 0.0023 & \\
& $(0.0025)$ & \\
Firm's support for further training * & & $-0.0203 *$ \\
years of education & & $(0.0122)$ \\
Controls & yes & yes \\
Adjusted $\mathrm{R}^{2}$ & 0.1608 & 0.1610 \\
\# Observations & 8,469 & 8,469 \\
\hline
\end{tabular}

Notes: Clustered robust standard errors at firm level in brackets *significant at $10 \%, * *$ significant at $5 \%$, ***significant at $1 \%$. Controls: female $(1=y e s)$, age, children $<14 \quad(1=y e s)$, in relationship ( $1=$ yes), years of education, big five ( 5 dummies), part-time ( 1 =yes), employment situation ( $1=$ yes), gross pay, collective agreement $(1=y e s)$, work's council ( $1=y e s)$, firm size (4 dummies), region (4 dummies), industry ( 5 dummies), incidence of HR instruments ( 8 dummies), average commitment of other firm employees, year

In order to disentangle the support effect from the participation effect, we combine the two facets of training in Model (4) of Table 4. Including all relevant further training variables in Model (4) shows that both measures-the individual participation in further training and the firm's support for further training-are relevant for affective commitment of employees. In this sense, employees may reciprocate to shown appraisals by the employer.

In order to investigate our Hypotheses ( $3 a$ ) and ( $3 b$ ), we extend our previous models by including interaction terms of firm's support for further training and years of education as well as age. Table 5 shows the results of the interaction terms of firm's support for further training and age (Model 1) as well as years of education (Model 2 ). The coefficients are insignificant for the case of age and only weakly significant, but even negative for the interaction with years of education. Hence at first glance, our expectation that younger and better educated employees who are supported by the firm are more highly committed to their organizations are not confirmed at all. However, the variable firm's support for further training represents a rather general measure for the support of employees in firms. If younger and better educated employees have higher expectations and special interests towards training possibilities a general support for all employees may not meet these higher expectation 
levels. Indeed, estimations of subgroups with regard to years of education show that the firm's general support for further training is not related to affective commitment for individuals with a university degree (15 + years of education). In contrast, the results indicate a particular relevance of participation in training for the group of university graduates (see Table D in the appendix). ${ }^{8}$ With regard to age, the positive relation of firm's support for further training and affective commitment is rather relevant for older employees $(40+)$. The relation between participation in training and commitment is robust among the whole age distribution (see Table E in the appendix). In order to catch at least part of differences in perceptions of employees based on potential heterogeneity in expectations and special interests as described above, we also extend our analysis by adding the variable Employee's perceived support which measures the employees' perceived support for personnel development by the firm on the individual level (five-point Likert scale from 1 "strongly disagree" to 5 "strongly agree"). ${ }^{9}$ Indeed, we find that the relation of an employee's perceived support and affective commitment is increasing with years of education and decreasing with age. Both results are robust in a joint estimation of the two interaction terms (see Table $\mathrm{F}$ in the appendix). ${ }^{10}$

We complement our analysis with the following robustness checks (see Table $\mathrm{G}$ in the appendix): First, we run our estimation model with the dependent variable turnover intention instead of affective commitment. The concept of commitment is argued to be relevant mainly because of its link to employee retention, which is an important objective of the human resource management of many firms. The participants are asked "How many times in the past 12 months have you thought about changing your job?" on a five-point Likert scale from 1 (never) to 5 (daily). The results regarding the participation effect are very similar compared to commitment. Second, we do not find differences across years when estimating separated cross-section models of single years. Additionally, our results are robust for gender subgroups. The relation of training - both participation in and support for-and affective commitment seems to be slightly (although not significantly) stronger for the subgroup of men. Moreover, we find that the results concerning firm's support for further training hold for the subgroups of employees who participate or do not participate in training, hinting again at its own independent role (see Model (6 and 7) of Table G). We also checked whether the relation between firm's support for further training and affective commitment holds across firm size categories, since larger firms spend more on formal training courses than smaller firms (De Kok

\footnotetext{
8 Additional estimations analyzing the interaction effect of participation in training and age as well as schooling show no significant results for the individual affective commitment (available by the authors upon request).

9 In Grund \& Titz (2018), we much more focus on the Employee's perceived support in order to measure the possible support effect from the individual level. However, we decided to drop this measure for this contribution due to a possible common method bias.

10 Note that a common method bias is likely to be relevant when examining the relation between employees' perceived support for personnel development and commitment in general. There is, however, no reason to believe that this potential bias is more pronounced for a specific group of individuals with respect to years of education.
} 
2002; Curran et al. 1997; Westhead and Storey 1996). Indeed, our results holds across all firm size categories (see Table $\mathrm{C}$ in the appendix). In order to catch some possible unobserved heterogeneity between employers we run a further OLS regression which includes employer dummies as control variables in addition (see Model (8) of Table G). Our results are still significant and robust. Unfortunately, the variation of our training variables over time is not sufficient for applying person fixed effects estimations. We have checked, however, that our main results are robust to a lagged dependent variable model. In spite of a considerable decrease in the number of observations, we still find a significantly positive relation of our two relevant training measures and affective commitment (see Model (9) of Table G).

Some further limitations of this paper should be acknowledged. First, due to the fact that the number of employees of each firm is rather small, the possibility of examining subgroups of employees within the firms is somewhat limited. Second, due to the possibility that employees with higher affective commitment tend to participate in further training or work in organizations with higher support for further training, the positive relation of further training and affective commitment could be the result of reverse causation. Indeed, Sauermann (2015) measures the degree of worker reciprocity and shows that the positive relation of firm-sponsored training and employee performance is relevant for reciprocal employees in particular. Accordingly, Non (2020) shows some evidence for a positive link between employees' degree of reciprocity and likelihood of participation in training. It is an important task for future research to investigate the interdependencies in more detail including possible selection effects of reciprocal employees to corresponding firms. Additionally, the information regarding the training variables is rather broad. Participation in further training and the firm's support for further training are captured by a binary variable. Research hints that training satisfaction plays an important role (Memon et al. 2016) and an involuntary nature of training measures can undermine the link to affective commitment (Newman et al. 2011). Information about different training opportunities, the frequency and intensity of training, or the amount of training support could lead to even more meaningful results.

\section{Conclusion}

In contrast to previous studies that mainly concentrate either on the relation of individual participation in further training and affective commitment or the firm's support for further training and affective commitment, this paper combines the two facets and investigates the relation between participation in training and affective commitment by taking the firm's perspective with regard to the provision of training into account. Additionally, the structure of the data allows us to control for a bundle of human resource management instruments that can also be related to individual affective commitment and which have not been considered in previous work. We find that participation in further training and a firm's support for further training are both significantly positively related to affective commitment of employees in separate analyses. Including the HR instruments as controls diminishes the reported relation of participation in further training and affective commitment. Hence, our 
results hint at a potential overestimation of the relation of further training and affective commitment in previous studies.

Our results hint-in line with signaling theory and perceived organizational support theory - that it is important for organizations to care about employees' further personnel development in terms of training possibilities in order to raise the individual affective commitment. The results also indicate that expectations towards the firm's support differ across subgroups. Providing some general support for all employees seems not to be sufficient for better educated employees with a university degree. For this, the relation of their own perceptions towards the firm support for their development and affective commitment is particularly pronounced, though. In this context, the time perspectives of the training variables seem to be highly relevant. Participation in further training refers to the present or immediate past situation of the employees. The same applies for the firm-based support variables. In contrast, the individuals' perception towards support for further development of knowledge is obviously more related to the future and the expectations of employees. An important implication for firms is, therefore, not to solely rely on present training measures as a commitment device, but to consider more futureoriented HR measures. For example, appraisal interviews may focus on individual future career development. This implication of the importance of future-oriented measures might also be relevant for other management issues in firms.

Future research may try to address the relation of further training and affective commitment over a longer period of time than two waves in order to monitor changes in employee attitudes over the career. More precise information about the volume, intensity, and type of further training in firms would also be desirable, since possible differences in training measures can lead to several different effects regarding the individual affective commitment, particularly when different groups of employees are analyzed. Moreover, with regard to the possible causality problem, additional information about employees' motivation to participate in further training on the one hand and about the firms' decision on who will be supported on the other hand would help to clarify the relation of further training and affective commitment in future research.

\section{Appendix}

Table A Items of Affective Commitment in LPP

\begin{tabular}{lc}
\hline $\begin{array}{l}\text { I would be very happy to spend the rest of my } \\
\text { career with this organization }\end{array}$ & $\begin{array}{l}\text { I do not feel a strong sense of "belonging" to my } \\
\text { organization. (R) }\end{array}$ \\
\hline $\begin{array}{l}\text { This organization has a great deal of personal } \\
\text { meaning for me }\end{array}$ & $\begin{array}{c}\text { I do not feel "emotionally attached" to this organiza- } \\
\text { tion. }(\mathrm{R})\end{array}$ \\
$\begin{array}{l}\text { I really feel as if this organization's problems are } \\
\text { my own }\end{array}$ & $\begin{array}{c}\text { I do not feel like "part of the family" at my organi- } \\
\text { zation. (R) }\end{array}$
\end{tabular}

Notes: These items are measured on a five-point Likert scale from 1 (does not apply at all) to 5 (fully applies) 


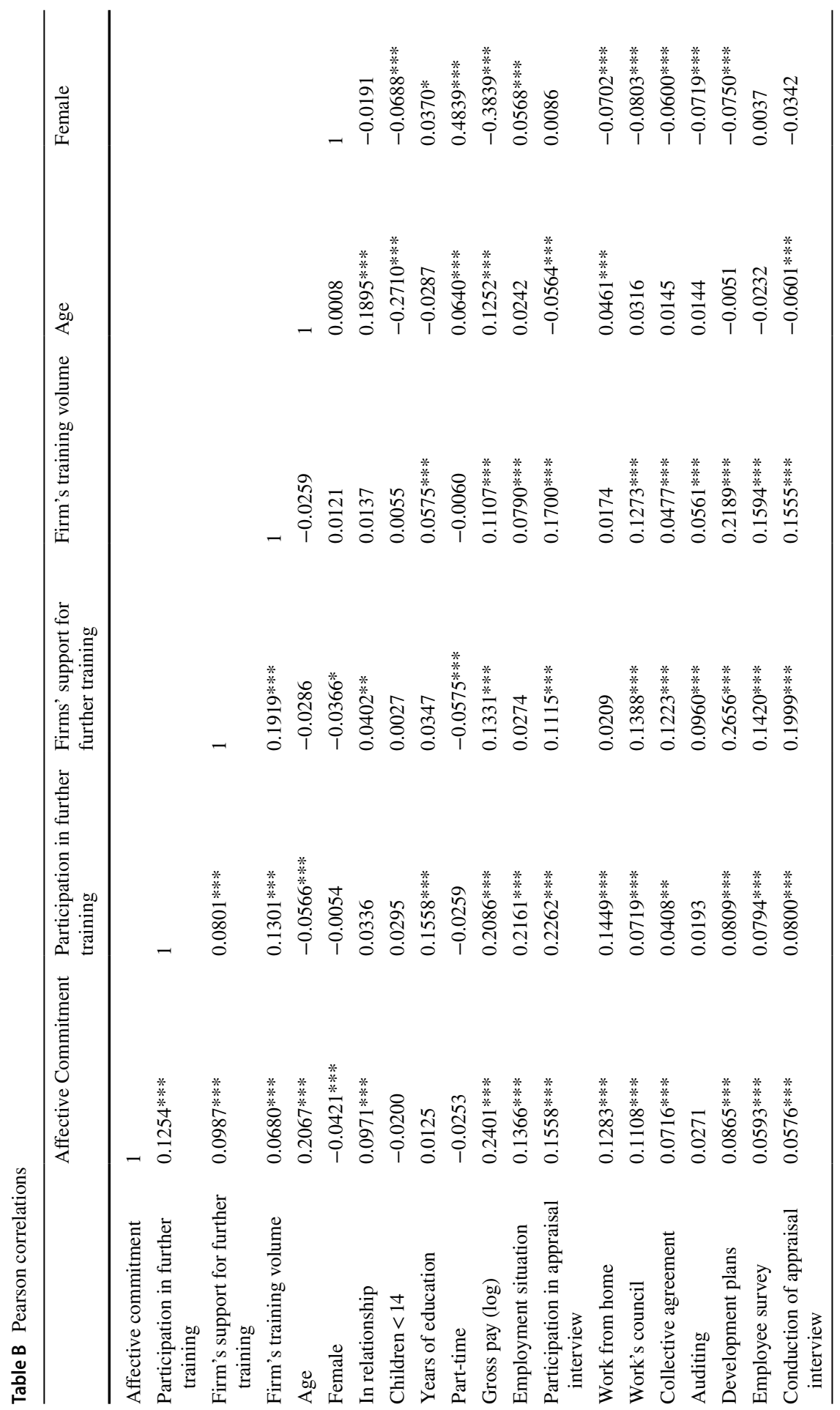




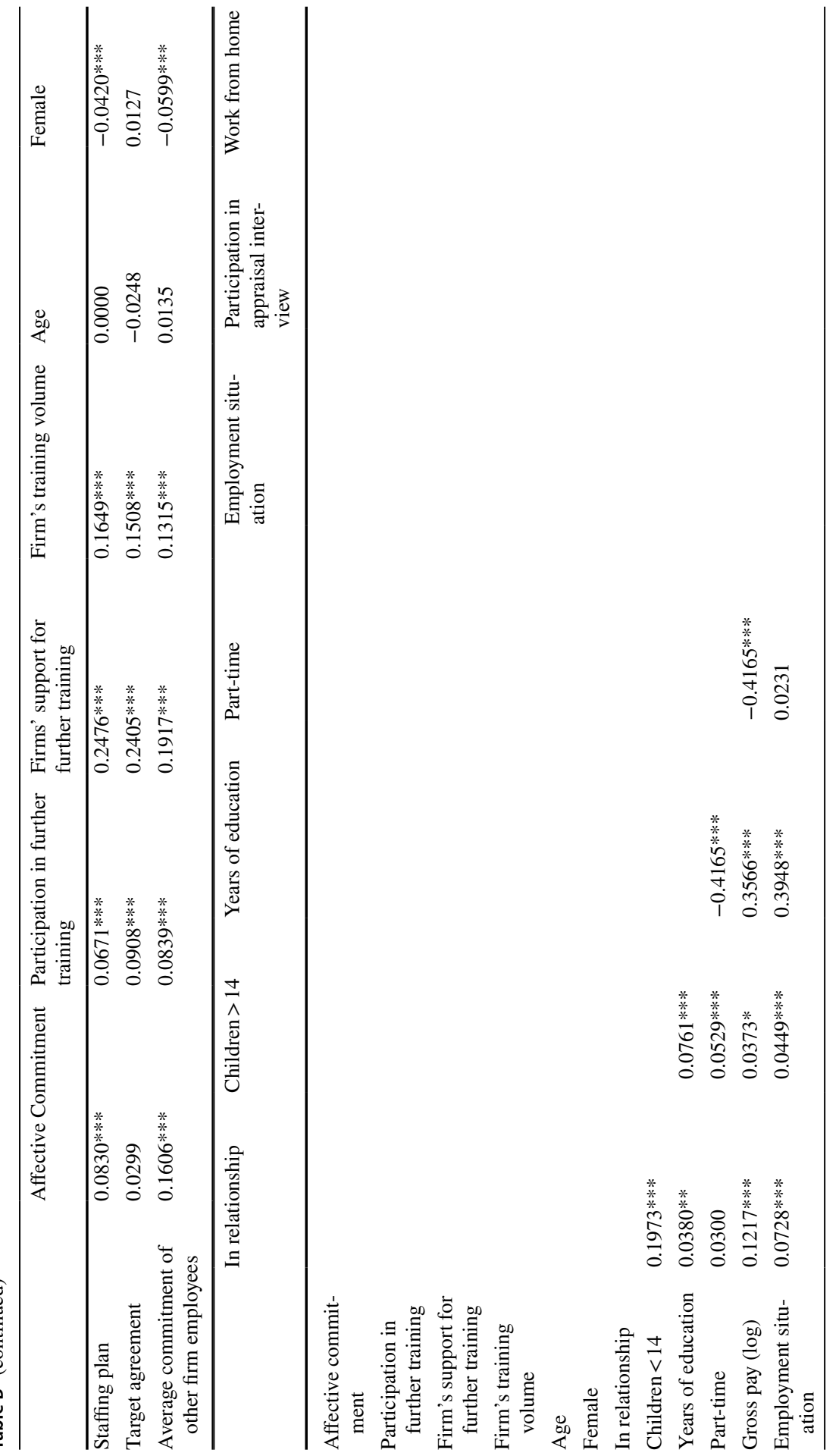




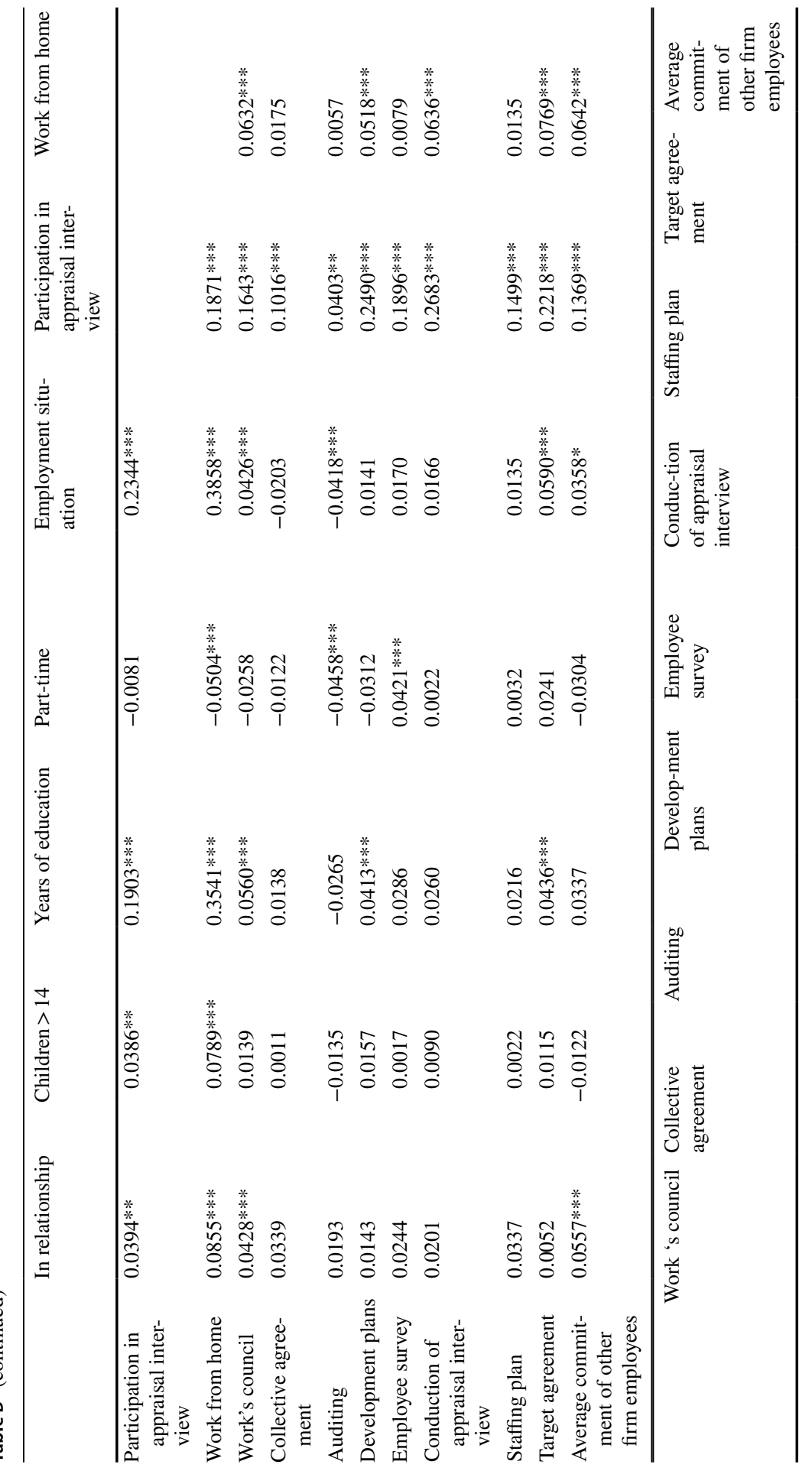




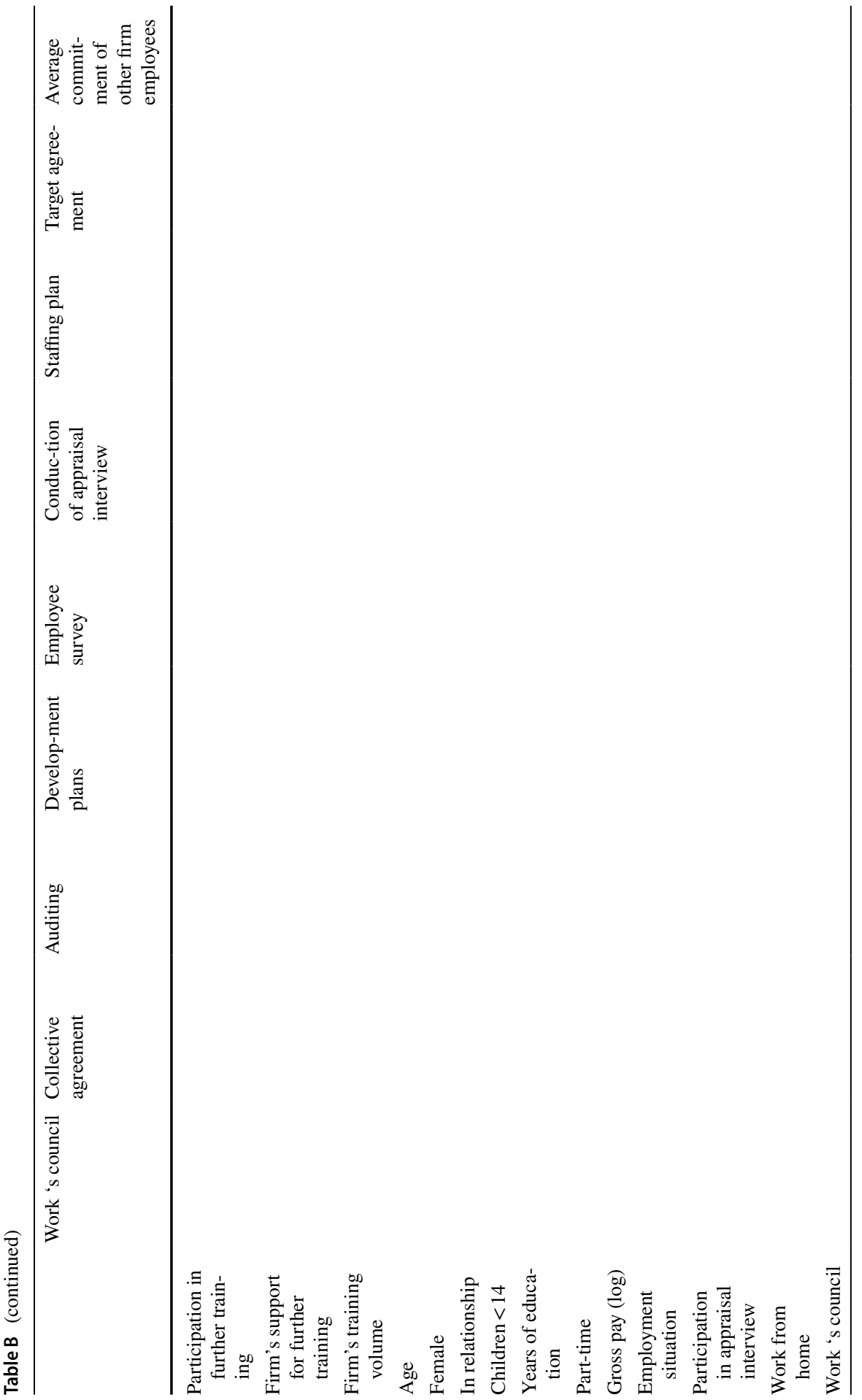




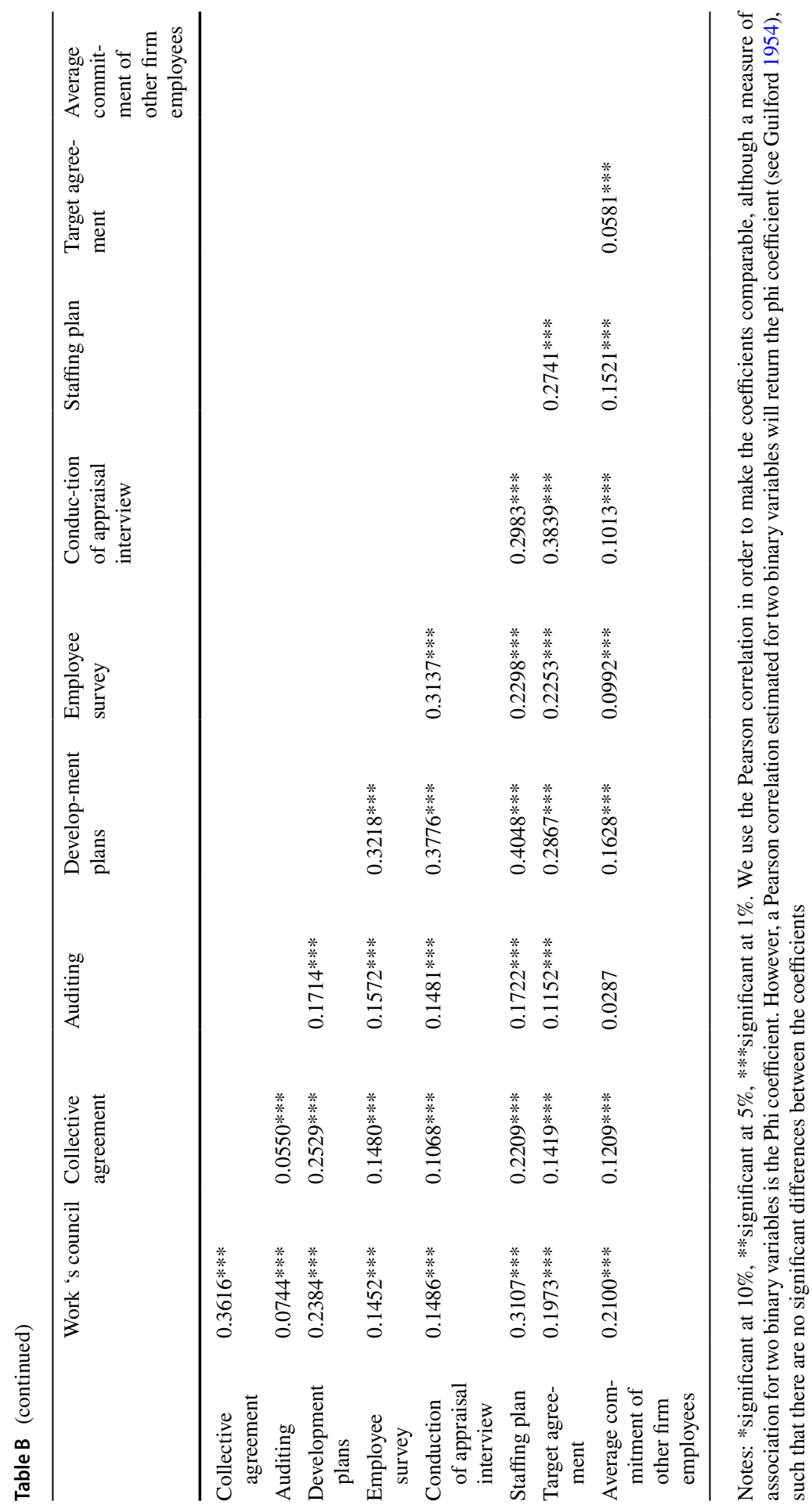


Table C Firm size categories (OLS)

\begin{tabular}{|c|c|c|c|c|}
\hline & \multicolumn{4}{|l|}{ Affective commitment } \\
\hline & $\begin{array}{l}(1) \\
<=249 \text { employees }\end{array}$ & $\begin{array}{l}\text { (2) } \\
>249 \text { employees }\end{array}$ & $\begin{array}{l}(3) \\
<=249 \text { employees }\end{array}$ & $\begin{array}{l}\text { (4) } \\
>249 \text { employees }\end{array}$ \\
\hline Firm's training volume & $\begin{array}{l}0.0322 \\
(0.0719)\end{array}$ & $\begin{array}{l}0.0532 \\
(0.0352)\end{array}$ & $\begin{array}{l}0.0104 \\
(0.0732)\end{array}$ & $\begin{array}{l}0.0437 \\
(0.0359)\end{array}$ \\
\hline $\begin{array}{l}\text { Firm's support } \\
\text { for further training }\end{array}$ & $\begin{array}{l}0.0918 * * \\
(0.0409)\end{array}$ & $\begin{array}{l}0.1579 * * * \\
(0.0408)\end{array}$ & $\begin{array}{l}0.0833^{* *} \\
(0.0408)\end{array}$ & $\begin{array}{l}0.1522 * * * \\
(0.0403)\end{array}$ \\
\hline $\begin{array}{l}\text { Participation in further } \\
\text { training }\end{array}$ & & & $\begin{array}{l}0.1990 * * * \\
(0.0367)\end{array}$ & $\begin{array}{l}0.1241 * * * \\
(0.0281)\end{array}$ \\
\hline Controls & yes & yes & yes & yes \\
\hline Adjusted $\mathrm{R}^{2}$ & 0.1552 & 0.1583 & 0.1621 & 0.1615 \\
\hline \# Observations & 3,270 & 5,199 & 3,270 & 5,199 \\
\hline
\end{tabular}

Notes: Clustered robust standard errors at firm level in brackets.

*significant at 10\%, **significant at 5\%, ***significant at 1\%. Controls: female ( $1=$ yes), age, children $<14$ ( $1=$ yes), in relationship ( $1=$ yes), years of education, big five ( 5 dummies), part-time $(1=$ yes $)$, employment situation $(1=y e s)$, gross pay, collective agreement $(1=$ yes $)$, work's council $(1=$ yes $)$, firm size $(4$ dummies), region (4 dummies), industry (5 dummies), incidence of HR instruments ( 8 dummies), average commitment of other firm employees, year

Table D Years of education categories (OLS)

\begin{tabular}{llll}
\hline & \multicolumn{2}{l}{ Affective commitment } & \\
\cline { 2 - 3 } & $\begin{array}{l}7-11.5 \text { years of educa- } \\
\text { tion }\end{array}$ & $\begin{array}{l}12-14.5 \text { years of } \\
\text { education }\end{array}$ & $\begin{array}{l}\text { 15-18 years } \\
\text { of education }\end{array}$ \\
\hline Firm's training volume & $\begin{array}{l}0.0575 \\
(0.0389)\end{array}$ & 0.0028 & -0.0453 \\
Firm's support & $0.1524^{* * *}$ & $(0.0910)$ & $(0.0676)$ \\
for further training & $(0.0343)$ & $0.1332^{* *}$ & 0.0079 \\
Participation in further training & $0.1426^{* * *}$ & $(0.0679)$ & $(0.0692)$ \\
Controls & $(0.0278)$ & $0.1107 * *$ & $0.2244^{* * *}$ \\
Adjusted $\mathrm{R}^{2}$ & yes & $(0.0515)$ & $(0.0468)$ \\
\# Observations & 0.1528 & yes & yes \\
\hline
\end{tabular}

Notes: Clustered robust standard errors at firm level in brackets.

*significant at $10 \%$, **significant at 5\%, ***significant at $1 \%$. Controls: female $(1=$ yes $)$, age, children $<14$ ( $1=$ yes), in relationship $(1=$ yes $)$, big five $(5$ dummies $)$, part-time $(1=$ yes), employment situation ( $1=$ yes), gross pay, collective agreement $(1=$ yes $)$, work's council $(1=$ yes $)$, firm size ( 4 dummies), region (4 dummies), industry (5 dummies), incidence of HR instruments ( 8 dummies), average commitment of other firm employees, year 
Table E Age categories (OLS)

\begin{tabular}{llll}
\hline & \multicolumn{2}{l}{ Affective commitment } \\
\cline { 2 - 4 } & $21-39$ years & $40-50$ years & $>=51$ years \\
\hline Firm's training volume & -0.0353 & 0.0321 & $0.1489^{* * *}$ \\
& $(0.0566)$ & $(0.0609)$ & $(0.0524)$ \\
Firm's support & 0.0588 & $0.1643^{* * *}$ & $0.1218^{* * *}$ \\
for further training & $(0.0561)$ & $(0.0506)$ & $(0.0465)$ \\
Participation in further training & $0.1170^{* * *}$ & $0.1676^{* * *}$ & $0.1638^{* * *}$ \\
& $(0.0432)$ & $(0.0367)$ & $(0.0355)$ \\
Controls & yes & yes & yes \\
Adjusted $\mathrm{R}^{2}$ & 0.1347 & 0.1238 & 0.1314 \\
\# Observations & 2,183 & 2,900 & 3,386 \\
\hline
\end{tabular}

Notes: Clustered robust standard errors at firm level in brackets.

*significant at $10 \%, * *$ significant at $5 \%, * * *$ significant at $1 \%$. Controls: female $(1=$ yes $)$, children $<14$ $(1=$ yes $)$, in relationship $(1=$ yes $)$, non-German nationals $(1=$ yes $)$, years of education, big five ( 5 dummies), part-time $(1=$ yes $)$, employment situation $(1=$ yes $)$, gross pay, collective agreement $(1=$ yes $)$, work's council ( $1=$ yes), firm size ( 4 dummies), region ( 4 dummies), industry ( 5 dummies), incidence of HR instruments ( 8 dummies), average commitment of other firm employees, year

Table F Employee's perceived support and affective commitment (interaction terms)

\begin{tabular}{llll}
\hline & OLS & & \\
\cline { 2 - 4 } & $(1)$ & $(2)$ & $(3)$ \\
\hline Firm's training volume & 0.0141 & 0.0144 & 0.0145 \\
Firm's support for further training & $(0.0304)$ & $(0.0305)$ & $(0.0303)$ \\
& $0.1232^{* * *}$ & $0.1235^{* * *}$ & $0.1247^{* * *}$ \\
Employee's perceived support & $(0.0254)$ & $(0.0254)$ & $(0.0254)$ \\
& 0.0749 & $0.3144 * * *$ & $0.1839^{* * *}$ \\
Participation in further training & $(0.0458)$ & $(0.0374)$ & $(0.0583)$ \\
& 0.0238 & 0.025 & 0.0231 \\
Age & $(0.0203)$ & $(0.0203)$ & $(0.0203)$ \\
& $0.0171^{* * *}$ & $0.0254^{* * *}$ & $0.0251^{* * *}$ \\
Years of education & $(0.0010)$ & $(0.0031)$ & $(0.0030)$ \\
& $-0.0624 * * *$ & $-0.024 * * *$ & $-0.0611^{* * *}$ \\
Employee's perceived support $*$ years of & $(0.015)$ & $(0.0048)$ & $(0.0150)$ \\
education & $0.0107 * * *$ & & $0.0103^{* * * *}$ \\
Employee's perceived support * age & $(0.0036)$ & & $(0.0036)$ \\
& & $-0.0023^{* * * *}$ & $-0.0022^{* * *}$ \\
Controls & & $(0.0008)$ & $(0.0008)$ \\
Adjusted $\mathrm{R}^{2}$ & yes & yes & yes \\
\# Observations & 0.3343 & 0.3344 & 0.3350 \\
\hline
\end{tabular}

Notes: Clustered robust standard errors at firm level in brackets.

$*$ significant at $10 \%, * *$ significant at $5 \%, * * *$ significant at $1 \%$. Controls: female $(1=$ yes $)$, age, children $<14$ $(1=$ yes), in relationship $(1=$ yes), non-German nationals $(1=$ yes), years of education, big five ( 5 dummies), part-time $(1=$ yes $)$, employment situation $(1=$ yes $)$, gross pay, collective agreement $(1=$ yes $)$, work's council ( $1=$ yes), firm size ( 4 dummies), region ( 4 dummies), industry (5 dummies), incidence of HR instruments (8 dummies), average commitment of other firm employees, year 


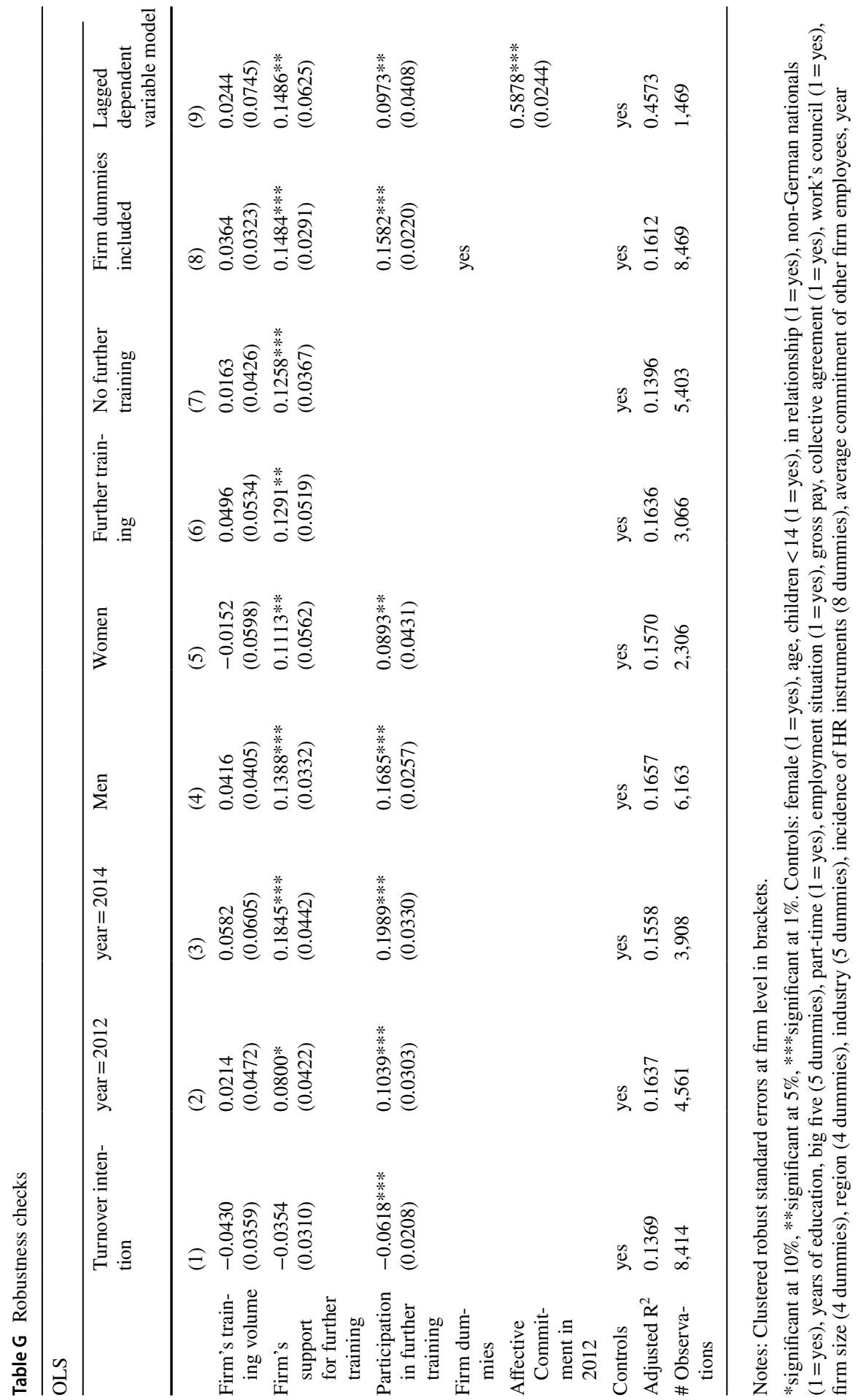


Funding Open Access funding enabled and organized by Projekt DEAL.

Open Access This article is licensed under a Creative Commons Attribution 4.0 International License, which permits use, sharing, adaptation, distribution and reproduction in any medium or format, as long as you give appropriate credit to the original author(s) and the source, provide a link to the Creative Commons licence, and indicate if changes were made. The images or other third party material in this article are included in the article's Creative Commons licence, unless indicated otherwise in a credit line to the material. If material is not included in the article's Creative Commons licence and your intended use is not permitted by statutory regulation or exceeds the permitted use, you will need to obtain permission directly from the copyright holder. To view a copy of this licence, visit http://creativecommons.org/licen ses/by/4.0/.

\section{References}

Ahmad KZ, Bakar RA (2003) The association between training and organizational commitment among white-collar workers in Malaysia. Int J Train Dev 7(3):166-185. https://doi.org/10.1111/1468-2419. 00179

Akerlof GA (1982) Labor contracts as partial gift exchange. Q J Econ 97(4):543-569. https://doi.org/10. $2307 / 1885099$

Akerlof GA (1984) Gift exchange and efficiency-wage theory: four views. Psycholo Sociol Found Econ Behav 74(2):79-83

Al-Emadi MAS, Marquardt MJ (2007) Relationship between employees' beliefs regarding training benefits and employees' organizational commitment in a petroleum company in the State of Qatar. Int J Train Dev 11(1):49-70. https://doi.org/10.1111/j.1468-2419.2007.00269.x

Allen NJ, Meyer JP (1990) The measurement and antecedents of affective, continuance and normative commitment to the organization. J Occup Organ Psychol 63(1):1-18. https://doi.org/10.1111/j.20448325.1990.tb00506.x

Ashford BE, Mael F (1989) Social identity theory and the organization. Acad Manag Rev 14(1):20-39

Backes-Gellner U, Tuor SN (2010) Avoiding labor shortages by employer signaling: on the importance of good work climate and labor relations. Ind Labor Relat Rev 63(2):271-286. https://doi.org/10.1177/ 001979391006300205

Bartlett KR (2001) The relationship between training and organizational commitment: a study in the health care field. Hum Resour Dev Q 12(4):335-352. https://doi.org/10.1002/hrdq.1001

Bartlett KR, Kang D (2004) Training and organizational commitment among nurses following industry and organizational change in New Zealand and the United States. Hum Resour Dev Int 7(4):423440. https://doi.org/10.1080/1367886042000299799

Bashir N, Long CS (2015) The relationship between training and organizational commitment among academics in Malaysia. J Manage Dev 34(10):1227-1245. https://doi.org/10.1108/JMD-01-2015-0008

Becker GS (1962) Investment in human capital: a theoretical analysis. J Polit Econ 70(5):9-49. https:// doi.org/10.1086/258724

Becker R (1991) Berufliche Weiterbildung und Berufsverlauf - Eine Längsschnittuntersuchung von drei Geburtenkohorten. Mitteilungen zur Arbeitsmarkt- und Berufsforschung 24(2):351-364

Bellmann L, Hübler O, Leber U (2018) Works council and training effects on satisfaction. Appl Econ Lett 26(14):1177-1181. https://doi.org/10.1080/13504851.2018.1540842

Bellmann L, Bender S, Bossler M, Broszeit S, Dickmann C, Gensicke M, ... Wolter S (2015) LPP-linked personnel panel, quality of work and economic success: longitudinal study in German establishments (data collection on the first wave). FDZ-Methodenreport 05/2015, Nürnberg. Retrieved from http://doku.iab.de/fdz/reporte/2016/DR_06-16_EN.pdf

Benson GS (2006) Employee development, commitment and intention to turnover: a test of 'employability' policies in action. Hum Resour Manag J 16(2):173-192. https://doi.org/10.1111/j.1748-8583. 2006.00011.x

Bergami M, Bagozzi RP (2000) Self-categorization, affective commitment and group self-esteems as distinct aspects of social identity in the organization. Br J Soc Psychol 39:555-577. https://doi.org/10. $1348 / 014466600164633$ 
Bergman M (2006) The relationship between affective and normative commitment: review and research agenda. J Organ Behav 27(5):645-663. https://doi.org/10.1002/job.372

Blau PM (1964) Exchange and power in social life. Wiley, New York

Bulut C, Culha O (2010) The effects of organizational training on organizational commitment. Int J Train Dev 14(4):309-322. https://doi.org/10.1111/j.1468-2419.2010.00360.x

Butts MM, Wendy JC, Tae SY (2013) How important are work-family support policies? a meta-analytic investigation of their effects on employee outcomes. J Appl Psychol 98(1):1-25. https://doi.org/10. $1037 / \mathrm{a} 0030389$

Cao J, Hamori M (2015) The impact of management development practices on organizational commitment. Hum Resour Manage 55(3):499-517. https://doi.org/10.1002/hrm.21731

Chew J, Chan CA (2008) Human resource practices, organizational commitment and intention to stay. Int J Manpow 29(6):503-522. https://doi.org/10.1108/01437720810904194

Cooper-Hakim A, Viswesvaran C (2005) The construct of work commitment: testing an integrative framework. Psychol Bull 131(2):241-259. https://doi.org/10.1037/0033-2909.131.2.241

Curran J, Blackburn R, Kitching J, North J (1997) Small firms and workforce training: some results, analysis and policy implications from a national survey. London: Small Firms: Enterprising Future

De Kok J (2002) The impact of firm-provided training on producation: testing for firm-size effects. Int Small Bus J 20(3):271-295. https://doi.org/10.1177/0266242602203003

Dietz D, Zwick T (2020) The retention effect of training-portability, visibility, and credibility. Int J Hum Resour Mange. https://doi.org/10.1080/09585192.2020.1737835

Eisenberger R, Huntington R, Hutchison S, Sowa D (1986) Perceived organizational support. J Appl Psychol 71(3):500-507

Erdheim J, Wang M, Zickar MJ (2006) Linking the big five personality constructs to organizational commitment. Personal Individ Differ 41(5):959-970. https://doi.org/10.1016/j.paid.2006.04.005

Fehr E, Gächter S (2000) Fairness and retaliation: The economics of reciprocity. J Econ Perspect 14(3):159-181. https://doi.org/10.1257/jep.14.3.159

Foreman P, Whetten DA (2002) Members' identification with multiple-identity organizations. Organ Sci 13:618-637. https://doi.org/10.1287/orsc.13.6.618.493

Gilani H, Cunningham L (2017) Employer branding and its influence on employee retention: a literature review. Market Rev 17(2):239-256. https://doi.org/10.1362/146934717X14909733966209

Gouldner AW (1960) The norm of reciprocity: a preliminary statement. Am Sociol Rev 25(2):161-178. https://doi.org/10.2307/2092623

Grund C (2013) Job preferences revealed by employee initiated job change. Int J Hum Resour Manag 24(15):2825-2850. https://doi.org/10.1080/09585192.2013.804689

Grund C, Titz K (2018) Further training and affective commitment. IZA Discussion Paper No 11403

Guilford JP (1954) Psychometric Methods, 2nd edn. McGraw-Hill Series, New York (in Psychology)

Hogg M, Terry D, White K (1995) A tale of two theories: a critical comparison of identity theory with social identity theory. Soc Psychol Quarter 58(4):255-269. https://doi.org/10.2307/2787127

Jirjahn U (2018) Works councils and employer attitudes toward the incentive effects of HRM practices. J Particip Emp Ownersh 1(2/3):98-127. https://doi.org/10.1108/JPEO-10-2017-0002

Jorgensen F, Becker K (2015) Balancing organizational and professional commitments in professional service firms: the HR practices that matter. Int J Hum Resour Manage 26(1):23-41. https://doi.org/ 10.1080/09585192.2014.925947

Kampkötter P, Marggraf K (2015) Do employees reciprocate to intra-firm trainings? an analysis of absenteeism and turnover rates. Int J Hum Resour Manage 26(22):2888-2907. https://doi.org/10.1080/ 09585192.2015.1005655

Kampkötter P, Mohrenweiser J, Sliwka D, Steffes S, Wolter S (2016) Measuring the use of human resources practices and employee attitudes. Evi Base HRM: a Glob Forum Empir Scholarsh 4(2):94-115. https://doi.org/10.1108/EBHRM-09-2015-0037

Konrad AM, Ritchie JE, Lieb P, Corrigalli E (2000) Sex differences in similarities in job attribute preferences: a meta-analysis. Psychol Bull 126(4):593-641. https://doi.org/10.1037/0033-2909.126.4.593

Kooij DTAM, Boon C (2018) Perceptions of HR practices, person-organization fit, and affective commitment: the moderating role of career stage. Hum Resour Manag J 28(1):61-75. https://doi.org/10. 1111/1748-8583.12164

Kooij DTAM, Jansen PGW, Dikker JSE, de Lange AH (2010) The influence of age on the associations between HR practices and both affective commitment and job satisfaction: a meta-analysis. J Organ Behav 31(8):1111-1136. https://doi.org/10.1002/job.666 
Lee CH, Bruvold NT (2003) Creating value for employees: investment in employee development. Int J Hum Res Manage 14(6):981-1000. https://doi.org/10.1080/0958519032000106173

Ling L, Qing T, Shen P (2014) Can training promote employee organizational commitment? the effect of employability and expectation value. Nankai Bus Rev Int 5(2):162-186. https://doi.org/10.1108/ NBRI-09-2013-0034

Mathieu ZE, Zajac DM (1990) A review and meta-analysis of the antecedents, correlates and consequences of organizational commitment. Psychol Bull 108(2):171-194

Memon MA, Salleh R, Baharom MNR (2016) The link between training satisfaction, work engagement and turnover intention. European J Train Dev 40(6):407-429. https://doi.org/10.1108/ EJTD-10-2015-0077

Mercurio ZA (2015) Affective commitment as a core essence of organizational commitment: an integrative literature review. Hum Resour Dev Rev 14(4):389-414. https://doi.org/10.1177/1534484315 603612

Meyer JP, Allen NJ (1991) A three-component conceptualization of organizational commitment. Hum Resour Manag Rev 1(1):61-89. https://doi.org/10.1016/1053-4822(91)90011-Z

Meyer JP, Allen NJ, Smith CA (1993) Commitment to organizations and occupations: extension and test of a three-component conceptualization. J Appl Psychol 78(4):538-551. https://doi.org/10.1037// 0021-9010.78.4.538

Meyer JP, Becker TE, van Dick R (2006) Social identities and commitments at work: toward an integrative model. J Organ Behav 27:665-683. https://doi.org/10.1002/job.383

Meyer JP, Herscovitch L (2001) Commitment in the workplace: toward a general model. Hum Resour Manag Rev 11:299-326. https://doi.org/10.1016/S1053-4822(00)00053-X

Meyer JP, Smith CA (2000) HRM practices and organizational commit-ment: test of a mediation model. Can J Adm Sci 17(4):319-331. https://doi.org/10.1111/j.1936-4490.2000.tb00231.x

Meyer JP, Stanley DJ, Herscovitch L, Topolnytsky L (2002) Affective, continuance, and normative commitment to the organization: a meta-analysis of antecedents, correlates, and consequences. J Vocat Behav 61(1):20-52. https://doi.org/10.1006/jvbe.2001.1842

Mowday RT, Steers RM, Porter LW (1979) The measurement of organizational commitment. J Vocat Behav 14(2):224-247. https://doi.org/10.1016/0001-8791(79)90072-1

Newman A, Thanacoody R, Hui W (2011) The impact of employee perceptions of training on organizational commitment and turnover intensions: a study of multinationals in the Chinese service sector. Int J Hum Res Manage 22(8):1765-1787. https://doi.org/10.1080/09585192.2011.565667

Non A (2020) Training participation and the role of reciprocal attitudes. CESifo Econ Stud 66(1):33-59. https://doi.org/10.1093/cesifo/ifz022

Porter LW, Steers RM, Mowday RT, Boulian PV (1974) Organizational commitment, job satisfaction, and turnover among psychiatric technicians. J Appl Psychol 59(5):603-609. https://doi.org/10.1037/ h0037335

Pratt MG (1998) To be or not to be? Central questions in organizational identification. In: Whetten DA, Godgrey PC (eds) Identity in organizations: Building theory through conversations. Sage, Thousand Oaks, CA, pp 171-207

Randall DM (1990) The consequences of organizational commitment: methodological investigation. J Organiza Behav 11(5):361-378. https://doi.org/10.1002/job.4030110504

Roehl WS, Swerdlow S (1999) Training and its impact on organizational commitment among lodging employees. J Hosp Tour Res 23(2):176-194. https://doi.org/10.1177/109634809902300205

Sauermann, J. (2015). Worker reciprocity and the returns to training: evidence from a field experiment. IZA Discussion Paper No. 9179, Available at SSRN: https://ssrn.com/abstract=2655128

Settoon RP, Bennett N, Robert CL (1996) Social exchange in organizations: perceived organizational support, leader-member exchange, and employee reciprocity. J Appl Psychol 81(3):219-227. https:// doi.org/10.1037//0021-9010.81.3.219

Sieben I (2007) Does raining trigger turnover-or not? The impact of formal training on graduates' job search behaviour. Work Employ Soc 21(3):397-416. https://doi.org/10.1177/0950017007080004

SOEP-IS Group (2017) SOEP-IS 2015.1-PGEN: Person-related Status and Generated Variables. SOEP Survey Papers 462: series D-Variable Descriptions and Coding. Berlin: DIW Berlin/SOEP

Spence M (1973) Job market signaling. Quart J Econ 87(3):355-374. https://doi.org/10.2307/1882010

Stegmeier J (2012) Effects of workplace representation on firm-provided further training in Germany. British J Ind Relat 50(4):667-689. https://doi.org/10.1111/j.1467-8543.2012.00895.x

Tajfel H (1974) Social identity and intergroup behaviour. Soc Sci Inf 13(2):65-93. https://doi.org/10. 1177/053901847401300204 
Van Vugt M, Hart CM (2004) Social identity as social glue: the origins of group loyalty. J Pers Soc Psychol 86:585-598. https://doi.org/10.1037/0022-3514.86.4.585

Wentland D (2003) The strategic training of employees model: balancing organizational constraints and training content, S.A.M. Adv Manage J 68:56-63

Westhead P, Storey DJ (1996) Management and training and small firm performance: why is the link so weak? Int Small Bus J 14(4):13-24

Publisher's Note Springer Nature remains neutral with regard to jurisdictional claims in published maps and institutional affiliations. 